\title{
PERAN PEMUDA MUSLIM DALAM PENGELOLAAN SAMPAH (STUDI ETIKA LINGKUNGAN HIDUP DI DESA KLANGONAN GRESIK)
}

\author{
${ }^{1}$ Ahmad Giri Ainuddin Muhammadi, ${ }^{2}$ Ni'matul Izza \\ ${ }^{1}$ UIN Sunan Ampel Surabaya, ${ }^{2}$ UNUSIA Jakarta \\ e-mail: agamgiri97@gmail.com
}

\begin{abstract}
Garbage is still an ongoing problem to be controlled, both by the government and individuals. In economic activities, for example, it can be seen how humans without feeling will always produce waste as in industrial-based economic activities. In addition to industrialbased economic activities, the development of the period with increasing population is one of the causes of the emergence of environmental problems including environmental pollution due to waste. The phenomenon that has always been a joint problematic is almost everywhere in every region including the village of Klangonan, Gresik district. The garbage problem in Klangonan village starts from the absence of a Temporary Disposal Site (TPS) in the village and the vacuum of the garbage collection officers, encourages the Klangonan village youth group who are members of the Karang Taruna Village Organization Klangonan (Katalog) to play a role in addressing these environmental problems (rubbish). By using descriptive research and qualitative approaches, the focus of this study are: 1. The pattern of waste management in Klangonan village. 2. Waste management strategy in Klangonan village. 3. Waste management application in Klangonan village.. By using the theory of the role of Biddle \& Thomas and theories in the study of environmental ethics as a knife for its analysis, this research resulted in the discovery that in responding to environmental problems especially waste, the Katalog youth initiated a waste management program in which youth held as actors in their implementation. Whereas in its implementation strategy, the Katalog youth cooperates with the village government as a medium for socialization and also supports the program. During the program, the youth in their application received positive responses from both the community and the village government.
\end{abstract}

Keywords: Youth of Karang Taruna, Waste Management, Environmental Ethics

\begin{abstract}
Abstrak: Sampah masih menjadi masalah yang tanpa henti untuk bisa dikendalikan, baik oleh pemerintah maupun perorangan. Dalam kegiatan ekonomi saja misalnya, terlihat bagaimana manusia tanpa terasa akan selalu menghasilkan sampah seperti dalam kegiatan ekonomi berbasis industri. Selain kegiatan ekonomi berbasis industri, Perkembangan masa dengan bertambahnya penduduk adalah salah satu penyebab dari munculnya masalah-masalah lingkungan yang di antaranya yaitu pencemaran lingkungan akibat sampah. Fenomena yang selalu menjadi problematika bersama itu hamper ada di setiap daerah tak terkecuali desa Klangonan, kabupaten Gresik. Problematika sampah di desa Klangonan yaitu berawal dari tidak adanya Tempat Pembuangan Sementara (TPS) di desa dan vakumnya petugas pengambil sampah, mendorong kumpulan pemuda desa Klangonan yang tergabung dalam organisasi Karang Taruna Desa Klangonan (Katalog) untuk berperan dalam menyikapi problematika lingkungan (sampah) tersebut. Dengan menggunakan penelitian deskriptif dan pendekatan kualitatif, fokus penelitian ini yaitu: 1. Pola pengelolaan sampah di desa Klangonan. 2. Strategi pengelolaan sampah di desa Klangonan. 3. Aplikasi pengelolaan sampah di desa Klangonan.
\end{abstract}


Dengan menggunakan teori peran Biddle \& Thomas serta teori-teori dalam studi etika lingkungan hidup sebagai pisau analisisnya, penelitian ini menghasilkan penemuan bahwa dalam merespon problematika lingkungan terutama sampah, pemuda Katalog menginisiasi sebuah program kelola sampah yang mana dalam hal ini pemuda memegang sebagai actor dalam pelaksanaannya. Sedangkan dalam strategi pelaksanaannya, pemuda Katalog menggandeng pemerintah desa sebagai media sosialisasi dan juga pendukung program. Selama program dijalankan, pemuda dalam aplikasinya mendapat respon positif baik dari masyarakat juga pemerintah desa.

Kata Kunci : Pemuda Karang Taruna, Pengelolaan Sampah, Etika Lingkungan Hidup.

\section{A. Pendahuluan}

Sampah masih menjadi masalah yang tanpa henti untuk bisa dikendalikan, baik oleh pemerintah maupun perorangan. Berdasarkan Undang-Undang Nomor 18 Tahun 2008, sampah didefinisikan sebagai sisa kegiatan sehari-hari manusia atau proses alam yang berbentuk padat atau semi padat berupa zat organic atau anorganik bersifat dapat terurai atau tidak dapat terurai yang dianggap sudah tidak berguna lagi dan dibuang ke lingkungan. Sampah telah menjadi residu di setiap hidup manusia yang bisa jadi menyusahkan atau sebaliknya yakni menguntungkan.kegiatan-kegiatan yang dilakukan oleh manusia dalam berbagai sector kehidupan juga turut andil dalam penumpukan sampah yang semakin menjadi akhir-akhir ini. Dalam kegiatan ekonomi saja misalnya, terlihat bagaimana manusia tanpa terasa akan selalu menghasilkan sampah seperti dalam kegiatan ekonomi berbasis industri. Manusia dengan industrinya setidaknya akan mengeluarkan limbah industry yang dibuang melalui saluran yang bermuara ke saluran drainase, sungai, atau bahkan ke laut. Jika limbah yang dihasilkan merupakan golongan limbah ynag bersifat cair maka limbah tersebut akan mencemari ekosistem laut. Sebaliknya apabila industry tersebut menghasilkan limbah yang bersifat non cair, maka yang terjadi adalah penumpukan benda padat baik berupa plastic, kertas, logam dan lainnya yang jumlahnya besar.

Perkembangan masa dengan bertambahnya penduduk adalah salah satu penyebab dari munculnya masalah-masalah lingkungan yang di antaranya yaitu pencemaran lingkunngan akibat sampah. Tingginya angka pertambahan penduduk akan berbanding lurus dengan volume sampah yang dihasilkan. Menurut Stewart dan Krier, masalah-masalah lingkungan dapat dikelompokkan menjadi tiga bagian, yaitu 
pencemaran lingkungan (pollution), pemanfaatan lahan secara salah (land misuse), dan pengurasan atau habisnya sumber daya alam (natural resource depeletion). ${ }^{1}$ Sedangkan di Indonesia masalah-masalah lingkungan dibagi menjadi dua, yakni pencemaran lingkungan dan perusakan lingkungan. Pencemaran lingkungan hiudp yaitu masuknya atu dimasukkannya makhluk hiudp, zat, energy, dan/atau komponen lain ke dalam linkgungan hidup oleh kegiatan manusia sehingga kualitasnya turun sampai ke tingkat tertentu yang menyebabkan lingkungan hiudp tidak dapat berfungsi sesuai dengan peruntukannya. ${ }^{2}$ Sedangkan perusakan lingkungan hidup adalah tindakan yang menimbulkan perubahan langsung atau tidak langsung terhadap sifat fisik dan/atau hayatinya yang mengakibatkan lingkungan hidup tidak berfungsi lagi dalam menunjang pembangunan berkelanjutan. ${ }^{3}$

Sampah adalah salah satu penyebab pencemaran lingkungan. Seiring dengan kenaikan angka penduduk di area perkotaan, maka demikian juga intensitas sampah akan bertambah pula atau meningkat. Menurut Badan Pusat Statistik (BPS) jumlah sampah pada tahun 2020 di 384 kota di Indonesia akan mencapai 80.235,87 ton tiap hari. Dari sampah yang dihasilkan tersebut diperkirakan sebesar 4,2\% akan diangkut ke Tempat Pembuangan Akhir (TPA), sebanyak 37,6\% dibakar, dibuang ke sungai sebesar 4,9\% dan tidak tertangani sekitar 53,3\%. Dari sekitar 53,3\% sampah yang tidak ditangani tersebut dibuang dengan cara tidak sanite.

Permasalahan sampah yang melanda setiap daerah juga tak lepas dari desa Klangonan. Dalam data Gresiknews diungkapkan bahwa Pemkab Gresik sudah mendorong munculnya bank sampah melalui Peraturan daerah (Perda) Kabupaten Gresik No. 5 tahun 2017 tentang pengelolaan sampah. ${ }^{4}$ Namun nampaknya peraturan ini belum mendapat respon maksimal dari beberapa desa di Gresik. Hal ini juga didasarkan bahwa Gresik pada masa tersebut belum mempunyai lahan TPA sendiri, dan selama ini masih menggunakan lahan yang dimiliki oleh perusahaan PT. Semen Gresik.

\footnotetext{
${ }^{1}$ Takdir Rahmadi, Hukum Lingkungan di Indonesia, (Jakarta: Rajawaloi Press, 2014), 1.

${ }^{2}$ Undang-Undang Nomor 23 Tahun 1997 tentang Pengelolaan Lingkungan Hidup Pasal 1 angka 12 . angka 14.

${ }^{3}$ Undang-Undang Nomor 23 Tahun 1997 tentang Pengelolaan Lingkungan Hidup Pasal 1

${ }^{4}$ Gresiknews.co, Kesadaran Mengelola Sampah di Gresik Masih Minim, 23 Oktober 2019. Diakses pada 14 November 2019, 12.30 WIB.
} 
Menanggapi fenomena tersebut, beberapa pemuda desa Klangonan mempunyai inisiatif untuk merubah cara pandang dalam memperlakukan sampah di daerahnya, yaitu dengan 4R (reduce, reuse, recycle, replace). Inisiatif yang telah banyak dilakukan masyarakat di beberapa daerah yang bahkan sampai menjadi sebuah usaha Bank Sampah ini terbukti mempunyai pengaruh baik bagi setiap daerahnya. Oleh karena itu kegiatan pemuda ini juga mendapat sambutan baik oleh masyarakat terutama dalam mengurangi efek sampah rumah tangga.

Dalam Undang-Undang Nomor 40 Tahun 2009 Tentang Kepemudaan juga disebutkan dalam pasal 17 bahwa peran aktif pemuda sebagai control sosial yaitu membangkitkan sikap kritis terhadap lingkungan dan penegakan hukum. Pun juga di pin selanjutnya peran aktif pemuda sebagai agen perubahan diwujudkan dengan mengembangkan: pendidikan politik dan demokratisasi; sumberdaya ekonomi; kepedulian terhadap masyarakat; ilmu pengetahuan dan teknologi; olahraga, seni, dan budaya; kepedulian terhadap lingkungan hidup; pendidikan kewirausahaan; dan/atau kepemimpinan dan kepeloporan pemuda. Jika dilihat beberapa poin di atas, pemuda desa Klangonan tersebut secara tidak langsung mengimplementasikan nilai-nilai tersebut.

Kemudian dalam konsep kehidupan yang terkategorisasi ini, sampah merupakan unsur abiotik yang artinya berbeda dengan manusia yang secara esensial mempunyai peranan penting di muka bumi. Jika dalam konsep antroposentrisme, permasalahan bencana ekologis lebih disudutkan kepadanya, maka kegiatan pemuda desa dalam menangani sampah ini mempunyai arti yang sedikit berbeda. Berangkat dari fenomena inilah penulis bermaksud untuk melakukan penelitian lebih mendalam terhadap peranan pemuda pada lingkungan desa terutama dalam pengolaan sampah, sehingga penelitian ini berjudul, Peran Pemuda Muslim dalam Pengelolaan Sampah (Studi Etika Lingkungan Hidup di Desa Klangonan Gresik). Dengan menggunakan metode penelitian deskriptif dengan pendekatan kualitatif. Penelitian deskriptif ialah suatu metode dalam membahas status kelompok manusia, suatu obyek, suatu kondisi, system pemikiran, ataupun suatu kelas peristiwa pada masa sekarang. Penelitian kualitatif menekankan pada penyajian data, menganalisis data dan menginterpretasikan data. Dengan menggunakan teori peran dan perspektif teori etika lingkungan hidup, penelitian ini diharapkan bisa menyajikan bentuk yang menyeluruh dalam menganalisis 
peran pemuda dalam pengelolaan sampah. Karena penelitian deskriptif merupakan penelitian yang berusaha untuk mendeskripsikan pemecahan masalah yang ada pada penelitian melalui data-data.

\section{B. Metode Penelitian}

Penelitian ini menggunakan jenis penelitian deskriptif kualitatif. Penelitian deskriptif kualitatif, yaitu penelitian yang mencoba untuk memberikan gambaran secara sistematis tentang situasi, permasalahan, fenomena ataupun menyediakan informasi. ${ }^{5}$ Peneliti menggunakan metode penelitian kualitatif dengan pertimbangan karena peneliti akan meneliti secara mendalam mengenai regulasi diri dalam pengembangan karakter religius. Oleh karena itu, penelitian kualitatif ini menggunakan teknik pengumpulan data berupa, observasi, wawancara mendalam, dan dokumentasi sehingga memudahkan proses penelitian. Melalui observasi di lapangan, peneliti akan mengetahui secara langsung bagaimana peran pemuda dalam pengelolaan sampah.

\section{Hasil dan Pembahasan}

\section{Teori Peran}

Teori Peran (Role Theory) adalah teori yang merupakan perpaduan berbagai teori, orientasi, maupun disiplin ilmu. Selain dari psikologi, teori peran berawal dari dan masih tetap digunakan dalam sosiologi dan antropologi. Dalam ketiga bidang ilmu tersebut, istilah "peran" diambil dari dunia teater. Dalam teater, seorang aktor harus bermain sebagai seorang tokoh tertentu dan dalam posisinya sebagai tokoh itu ia diharapkan untuk berperilaku secara tertentu. ${ }^{6}$

Posisi aktor dalam teater (sandiwara) itu kemudian dianalogikan dengan posisi seseorang dalam masyarakat. Sebagaimana halnya dalam teater, posisi orang dalam masyarakat sama dengan posisi actor dalam teater, yaitu bahwa perilaku yang diharapkan daripadanya tidak berdiri sendiri, melainkan selalu berada dalam

\footnotetext{
${ }^{5}$ Restu Kartiko Widi, Asas Metodologi Penelitian, (Yogyakarta: Graha Ilmu, 2010), 47.

${ }^{6}$ Sarlito Wirawan Sarwono, Teori-teori Psikologi social, (Jakarta: PT. RajaGrafindo Persada, 2017), 215.
} 
kaitan dengan adanya orang-orang lain yang berhubungan dengan orang atau actor tersebut. Dari sudut pandang inilah disusun teori-teori peran. ${ }^{7}$

Sebetulnya cukup banyak teori peran dalam psikologi, salah satunya adalah teori Biddle \& Thomas (1966). Dalam teorinya Biddle \& Thomas membagi peristilahan dalam teori peran dalam empat golongan, yaitu istilah-istilah yang menyangkut: ${ }^{8}$
a. Orang-orang mengambil bagian dalam interkasi sosial.
b. Perilaku yang muncul dalam interaksi tersebut.
c. Kedudukan orang-orang dalam perilaku.
d. Kaitan antara orang dan perilaku.

\section{Etika Lingkungan Hidup}

Secara teoretis, etika mempunyai pengertian, sebagai berikut. Pertama, secara etimologis, etika berasal dari kata Yunani ethos (jamaknya: ta etha), yang berarti "adat istiadat" atau "kebiasaan". Dalam arti ini, etika berkaitan dengan kebiasaan hidup yang baik, tata cara hidup yang baik, baik pada diri seseorang atau masyarakat. Kebiasaan hidup yang baik ini dianut dan diwariskan dari satu generasi ke generasi lain. ${ }^{9}$

Lingkungan hidup dipahami sebagai oikos dalam bahasa Yunani, yang artinya habitat tempat tinggal atau rumah tempat tinggal. Secara etimologis oikos dipahami dalam padanan yang lebih utuh dengan logos menjadi oikos dan logos, ecology, ekologi. Logos berarti ilmu atau kajian. Karena itu, lingkungan hidup dapat pula dipahami sebagai sebuah ilmu, yaitu ilmu tentang ekosistem dengan segala hubungan saling pengaruh di antara ekosistem dan isinya serta keseluruhan dinamika dan perkembangan yang berlangsung di dalamnya. ${ }^{10}$

Etika lingkungan hidup mempunyai beberapa teori. Dalam buku Sonny Keraf menjelaskan di antara teorinya yakni antroposentrisme, biosentrisme, ekosentrisme, dan terakhir ada ekofeminisme. Dari beberapa teori tersebut menghasilkan beberapa prinsip etika lingkungan hidup yang diambil dari biosentrisme dan ekosentrisme. Prinsip-prinsip ini yang kemudian akan

\footnotetext{
${ }^{7}$ Sarlito Wirawan Sarwono, Teori-Teori Psikologi...,, 215.

${ }^{8}$ Sarlito Wirawan Sarwono, Teori-teori Psikologi..., 216

${ }^{9}$ A. Sonny Keraf, Etika Lingkungan Hidup, (Jakarta: PT. Kompas Media Nusantara, 2010), 14.

${ }^{10}$ A. Sonny Keraf, Filsafat Lingkungan Hidup...., 44.
} 
direpresentasikan pada perilaku pemuda Karang Taruna Desa Klangonan terhadap pengelolaan sampah. Prinsip-prinsip etika lingkungan hidup tersebut yaitu:

a. Sikap hormat terhadap alam (respect for nature)

b. Prinsip tanggung jawab (moral responsibility for nature)

c. Solidaritas kosmis (cosmic solidarity)

d. Prinsip kasih sayang dan kepedulian terhadap alam (caring for nature)

e. Prinsip (no harm)

f. Prinsip hidup sederhana dan selaras dengan alam

g. Prinsip keadilan

h. Prinsip demokrasi

i. Prinsip integritas moral

Kemudian dalam segi manajemen lingkungan, Buchholz (1993) membaginya menjadi dua bagian yaitu manajemen tradisional dan manajemen ekosentris. Manajemen tradisional merupakan sebuah bentuk pengelolaan yang masih menganut paham antroposentrisme, sedangkan manajmen ekosentris merupakan kebalikan daripada tradisional. Bentuk pengelolaan ekosentris lebih mengutamakan keberlanjutan, kualitas hidup dan kesejahteraan. Perbedaan mendasar antara kedua manajemen tersebut terletak pada bagaimana cara memandang dan memanfaatkan peran lingkungan terhadap pemenuhan kebutuhan manusia. Perubahan fundamental untuk bumi lebih baik adalah dimulai dari transformasi moral atau etika manusia. Sebagai komunitas yang penting bagi lingkungan, pemulung termasuk dalam salah satu wujud dari manajemen ekosntris, namun masih belum dipandang penting bagi pengelolaan sampah berkelanjutan. ${ }^{11}$

Menurut Amurwaraharja, ada empat aspek yang perlu dipertimbangkan dalam penentuan alternative pengelolaan sampah, yaitu aspek sosial, lingkungan, ekonomi, dan teknis. Criteria dari aspek sosial seperti dalam hal penyerapan tenaga kerja, potensi konflik, penumbuhan sector formal dan informal, penumbuhan lapangan usaha, serta penguatan peran masyarakat. Kemudian dalam aspek ekonomi yaitu investasi rendah, biaya operasional yang ekonomis, dan adanya pendapatan asli daerah. Selanjutnya dalam aspek lingkungan yaitu meminimalisasi

\footnotetext{
${ }^{11}$ Rizqi Puteri Mahyudin, "Strategi Pengelolaan Sampah Berkelanjutan”, Jurnal Enviro Scientiae, Vol. 10 No. 2 (2014), 33-40
} 
pencemaran air, udara, dan tanah, mencegah biit penyakit, dan pertimbangan estetika lingkungan. Terkahir dalam hal teknis yaitu efektivitas pengurangan sampah, mengatasi keterbatasan lahan, ketersediaan lokasi, teknologi, dan pemanfaatan sumber daya. ${ }^{12}$ Sedangkan menurut Mahyudin, aspek-aspek yang perlu diperhatikan dalam strategi pengelolaan sampah berdasarkan prioritas dengan menggunakan Analytical Hierarchi Process yaitu kebijakan pemerintah, linkgungan, pembiayaan, kesehatan, dan persepsi masyarakat. ${ }^{13}$

\section{Mekanisme Pengelolaan Sampah}

\section{a. Fenomena sampah dan perilaku masyarakat}

Desa klangonan merupakan desa yang mempunyai masyarakat dengan pekerjaan industri rumahan yang terbilang banyak. Kondisi tersebut bisa dilihat dari banyaknya pedagang makanan ringan yang hadir sebagai bentuk keanekaragaman profesi masyarakat desa. Produksinya pun terbilang massif, itu dikarenakan kawasan wisata religi Sunan Giri yang tidak pernah sepi dalam setiap tahunnya. Kondisi tersebut membuka peluang besar bagi masyarakat desa Klangonan untuk mengembangkan bisnisnya dalam skala desa. Namun bersamaan dengan hal tersebut, semakin naik pula volume sampah yang dihasilkan masyarakat dalam proses wirausahanya.

Sebenarnya sampah adalah perihal masalah tahunan yang tidak perlu dihadapi dengan kekhawatiran yang besar. Namun sedikit berbeda dengan kondisi desa Klangonan yang mana dalam urusan sampah, desa tidak mempunyai Tempat Pembuangan Sementara (TPS) sehingga mau tidak mau masyarakat yang menghasilkan sampah dengan volume tinggi atau rendah, misalnya sampah rumah tangga harus keluar desa untuk membuang sampah. Tempat Pembuangan Sementara (TPS) yang berada dekat dengan desa Klangonan terdapat tiga tempat, yang mana dua buah terletak di desa Sekarkurung sedangkan satunya terletak di pasar tradisional Giri. Selain

\footnotetext{
${ }^{12}$ Amurwaraharja, I.P, Analisis Teknologi Pengolahan Sampah Dengan Proses Hirarki Analitik dan Metoda Valuasi Kontingensi (Studi Kasus di Jakarta Timur), (Institut Pertanian Bogor, Tesis, 2003).

${ }^{13}$ Mahyudin, R.P, Strategi Pengelolaan Sampah Berkelanjutan, EnviroScientae, 10: 33-40.
} 
menyita waktu, kondisi tersebut juga mengorbankan tenaga untuk menjaga kebersihan lingkungan baik rumah maupun lingkungan desa. ${ }^{14}$

Dampaknya, dengan tipe desa yang luasnya setengah bangunan perumahan dan setengahnya lahan kosong memberi pilihan pada warga untuk memilih pembuangan yang lebih praktis. Hal itu dilakukan lantaran sebagian warga merasa jauh hingga sebagian warga juga membuang sampah di saluran air atau drainase, di lahan kosong dekat rumah, atau juga dibunag kemudian dibakar sehingga tidak terlalu menumpuk meskipun secaca penguraian plastic masih tetap ada dan akhirnya melekat pada tanah tanpa menyatu. Sebenarnya dulu ada petugas keliling yang mengambili sampah yang berada di desa Klangonan dengan system retribusi, namun hal itu akhirnya vakum pada tahun 2015 dan melahirkan perilaku masyarakat yang dijabarkan di atas, meskipun tidak sedikit juga yang masih membuang langsung ke Tempat Pembuangan Sementara (TPS) baik di Sekarkurung maupun pasar tradisional Giri. ${ }^{15}$

\section{b. Mekanisme Pengelolaan Sampah}

Sejak terbentuk pada tahun 2013, pemuda yang tergabung dalam Karang Taruna Desa Klangonan (Katalog) ini hanya bersifat partisipatif dan berkumpul untuk berdiskusi mengenai hal apapun untuk menjaga soliditas pemuda. Materi diskusi yang dibahas bermacam-macam dari hal yang bersifat permainan, perjalanan atau traveling hingga kondisi desa. Dari sinilah muncul inisiatif pemuda dalam menghadapi permasalahan sampah yang ada di desa Klangonan. Sejak tahun 2015 dan hampir setahun setengah kondisi sampah membuat masyarakat melakukan perilaku kepada sampah tanpa adanya petugas pengambil sampah. Pada pertengahan tahun 2016, berangkat dari permasalahan tersebut pemuda terjun untuk berpartisipasi dalam pembangunan desa di bidang lingkungan.

Tahun 2016 merupakan tahun di mana Karang Taruna Desa Klangonan (Katalog) masih belum mempunyai Surat Keputusan (SK) sebagai organisasi legal yang berfungsi secara administrative. Namun itu tidak menjadi penghalang bagi pemuda Karang Taruna Desa Klangonan (Katalog) dalam

\footnotetext{
${ }^{14}$ Wawancara dengan IB, pada 12 Juni 2019.

${ }^{15}$ Wawancara dengan IB, pada 12 Juni 2019.
} 
merespon kondisi desanya. Dengan melibatkan beberapa pemuda yang dikoordinatori ole Ibrahim, akhirnya petugas pengambilan sampah diambil alih oleh pemuda desa hingga sekarang. ${ }^{16}$ Ada beberapa langkah yang diambil pemuda ketika melaksanakan program lingkungan ini, yaitu:

1) Sosialisasi dan dukungan pemerintah desa ${ }^{17}$

Walaupun pada akhirnya mendapat sambutan baik oleh sebagian masyarakat, program ini melalui tahapan dalam pemberitahuan. Pada awalnya pemuda hanya menggunakan komunikasi buka pintu, artinya dari mulut ke mulut sehingga program ini bisa terdengar oleh semua masyarakat desa Klangonan. Kemudian pada saat yang sama juga pemuda menggandeng pemerintah desa untuk melakukan sosialisasi kepada masyarakat bahwa akan ada program lingkungan dari pemuda Karang Taruna Desa Klangonan (Katalog) dalam bentuk jasa pengambilan sampah. Hal itu diutarakan sebagai bentuk respon pemuda terhadap keresahan warga dan lingkungan. Pemerintah desa juga menanggapi program ini dengan positif. Hal tersebut terlihat dari dukungan pemerintah desa dalam memberikan fasilitas motor tossa sebagai alat mobilisasi dan bangunan tempat pemilahan.

2) Peralatan program ${ }^{18}$

Adapun peralatan yang digunakan dalam program ini adalah:

1) Motor tossa

2) Tongkat pengurai

3) Sekop

\footnotetext{
${ }^{16}$ Wawancara dengan M. CM pada 10 Juni 2019

${ }^{17}$ Wawancara IB pada 13 Juni 2019

${ }^{18}$ Wawancara IB pada Juni 2019
} 


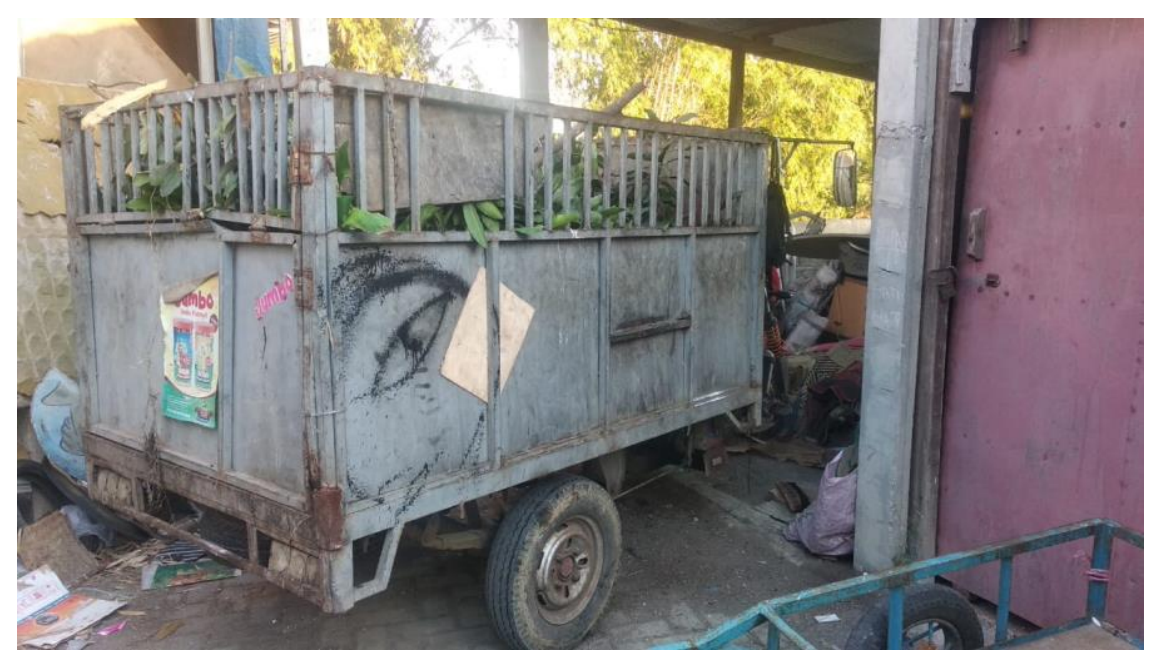

Gambar C.2.b. Tossa sebagai alat pengangkut sampah

3) Jadwal dan titik lokasi program

Pada mulanya Pemuda Karang Taruna Desa Klangonan (Katalog) yang bertugas berangkat dari jam 6 pagi sampai selesai di jam 2, dan bisa jadi sampai jam 4 sore. Namun sekarang hanya sampai siang dikarenakan Tempat Pembuangan Akhir (TPA) kota hanya sampai jam 1 siang.

Program ini terbagi menjadi beberapa bagian dan kloter, yaitu:

1) Senin : sasaran pengambilan yaitu RT 1 sampai dengan RT 6

2) Selasa : sasaran pengambilan yaitu RT 7 sampai dengan RT 13

3) Rabu : libur

4) Kamis : kembali dengan RT 1 sampai dengan 6

5) Jumat : kembali dengan RT 7 sampai dengan 13

6) Sabtu : desa luar (Sekarkurung dan Sidomukti)

7) Minggu: pemilahan 


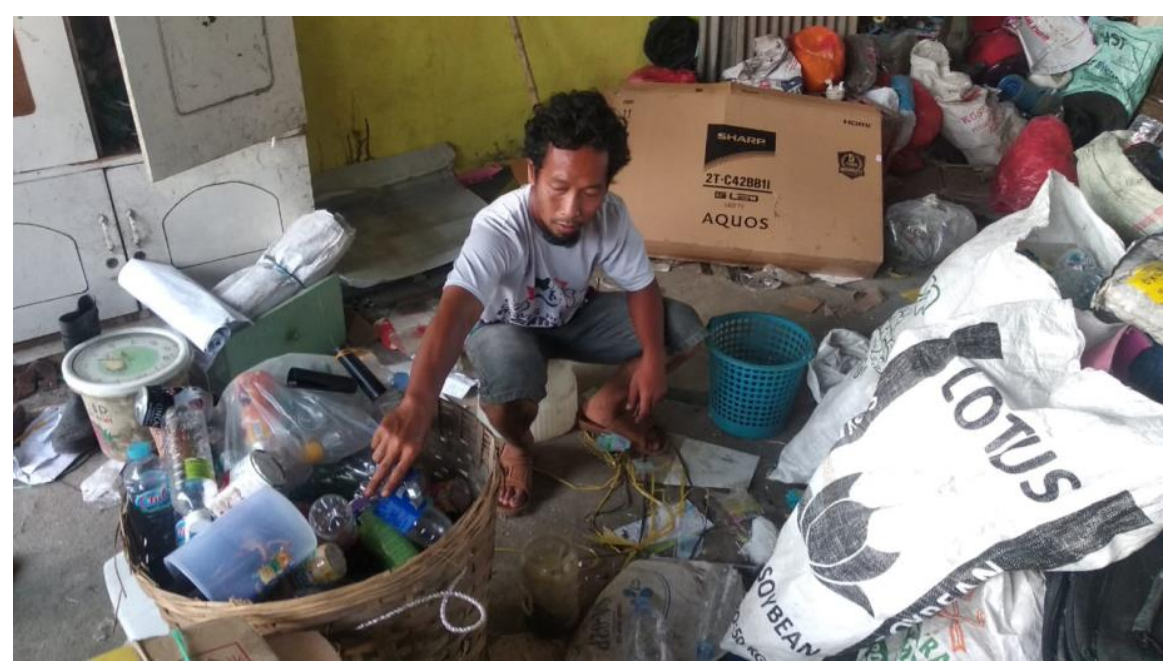

Gambar C.2.c Proses Pemilaban

4) Sistem kerjasama ${ }^{19}$

Program ini dilaksanakan dengan sasaran masyarakat desa. Bagi warga desa yang ingin mendapat jasa tersebut bisa langsung menggunakannya dengan berpartisipasi dalam pembuangan tanpa registrasi atau lainnya. Ini dikarenakan sistem mobilisasi pemuda yang mempermudah warga desa. Dengan menciptakan simbiosis mutalisme ini warga dimudahkan dalam urusan sampah. Sedangkan dalam biaya jasa, warga dikenakan retribusi 3000 rupiah per satu kali buang atau dengan 20.000 rupah per bulan bagi warga desa Klangonan, sedangkan yang nonwarga dikenakan retribusi sebesar 25.000 per bulan. Sehingga dalam penghasilan per keliling bisa mendapatkan 100.000 sampai dengan 240.000 rupiah.

5) Konsep tata kelola ${ }^{20}$

1) Kategorisasi sampah

Pada mulanya program lingkungan ini bermula sebagai bentuk pertolongan pada masyarakat, namun karena mendapat respon positif, program ini aktif hingga sekarang dan berkembang. Dalam proses pengambilan sampah, pemuda membedakan menjadi dua bagian, yaitu:

\footnotetext{
${ }^{19}$ Wawancara dengan IB pada 13 Juni 2019

${ }^{20}$ Wawancara dengan IB pada 13 Juni 2019.
} 
sampah yang dibuang dan sampah yang dikumpulkan untuk dipilah. Sampah yang dibuang adalah sampah-sampah yang kurang mempunyai nilai manfaat atau belum pada tahap rencana pemanfaatan. Sedangkan sampah yang dikumpulkan untuk dipilah yaitu sampah yang menurut warga desa tidak lagi digunakan namun bagi pemuda dikumpulkan untuk kemudian dipilah ulang sesuai nilai dan jenisnya.

Untuk sampah yang dibuang ditempatkan di Tempat Pembuangan Akhir (TPA) kota yang berada di wilayah PT. Semen Gresik menggunakan motor tossa, sedangkan sampah yang untuk dipilah ditempatkan di tempat pemilahan yang lokasinya terdapat di antara sekretariat Karang Taruna Desa Klangonan (Katalog) dan warung Katalog. Dalam sehari program ini bisa mengumpulkan 4 (empat) kubik sampah. Beberapa macam sampah yang masuk dalam tempat pemilahan juga mempunyai nilai jual, seperti:
1) Kertas
: 700 rupiah $/ \mathrm{kg}$
2) Kardus
: 1.200 rupiah $/ \mathrm{kg}$
3) Plastik
a) Bak : $1.500 \mathrm{rupiah} / \mathrm{kg}$
b) Blowing : $2.500 \mathrm{rupiah} / \mathrm{kg}$
c) Pet $\quad: 1.500 \mathrm{rupiah} / \mathrm{kg}$
d) Pepe $: 1.500$ rupiah $/ \mathrm{kg}$
e) PVC : $800 \mathrm{rupiah} / \mathrm{kg}$

6) Daur ulang ${ }^{21}$

Sebagai pemuda yang mempunyai hasrat berkembang dalam segi kreativitas, sampah hasil pemilahan tidak semuanya dijual seperti tidak semuanya dibuang. Sebagian sampah yang masih mempunyai nilai manfaat lebih, digunakan untuk kepentingan perkembangan kreativitas pemuda seperti mendaur ulang plastik. Kegiatan ini melibatkan pemuda dan remaja bahkan anak-anak untuk menanamkan pola pikir bahwa sampah tidak

\footnotetext{
${ }^{21}$ Wawancara dengan M CM pada 10 Juni 2019.
} 
sepenuhnya tidak berguna, melainkan ada manfaat yang bisa diraih selagi kita mempunyai daya inovasi yang cukup.

Program daur ulang ini juga bertujuan untuk menumbuhkan cinta lingkungan pada setiap warga desa Klangonan dari anak-anak hingga dewasa. Biasanya daur ulang dilaksanakan di waktu luang dan berdasarkan hasil observasi sebagian pemuda yang kemudian diwujudkan dalam bentuk eksperimen daur ulang pada momentum tertentu. Hasil yang telah dibuat sebagian dipajangkan pada warung Katalog sebagai dokumentasi hasil karya local yang bisa dilihat setiap warga yang melewati atau mampir di warung Katalog. Kemudian, lanjut lelaki yang disapa Awik tersebut menerangkan bahwa baru-baru ini juga sampah hasil dari warga berupa ember cat didaur ulang dengan bekerjasama dengan pemerintah desa dalam membuat tempat cuci tangan demi menanggulangi pandemic corona dan penerapan perilaku hidup bersih dan sehat.

\section{Prinsip Pengelolaan Sampah Dalam Etika Lingkungan Hidup}

Menurut Undang-Undang, sumber sampah adalah asal timbulan sampah. Sumber sampah yang berada di sekeliling masyarakat pada umumnya berkaitan erat dengan penggunaan lahan dan penempatan. Beberapa sumber sampah dapat diklasifikasikan antara lain: perumahan, komersil, institusi, konstruksi dan pembongkaran, pelayanan perkotaan, unit pengolahan, industri, dan pertanian. ${ }^{22}$

Sumber sampah yang berada di desa Klangonan jika dikategorikan menurut Gelbert, maka sampah yang dihasilkan lebih banyak pada sampah permukiman dan sebagian sampah industri atau disebut dengan pabrik yang berada di desa Klangonan. Sampah permukiman lebih banyak mendominasi di daerah tersebut terlebih rumah yang berwirausaha di kawasan wisata religi Sunan Giri.

Pola pengelolaan sampah yang dilakukan oleh pemuda Katalog yaitu sebagai berikut:

\footnotetext{
${ }^{22}$ G. Theisen Tchobanoglous, dan S. A. Vigil, Integrated Solid Waste Management Engineering Principles and Management Issues. (Singapore, Mc. Grw Hill, 1993)
} 
1. Pengambilan : merupakan kegiatan pengambilan sampah dengan mengelilingi desa dari rumah ke rumah sesuai dengan jadwal pengambilan.

2. Pengumpulan : merupakan sampah yang telah diambil kemudian dikumpulkan di tempat pemilahan yang berada di sebelah secretariat Karang Taruna.

3. Pemilahan : merupakan kegiatan memilah sampah untuk digolongkan berdasarkan jenis sampah dan nilai sampah.

4. Pengolahan : merupakan kegiatan pengolahan dalam bentuk daur ulang yang digunakan untuk menumbuhkan daya kreativitas pemuda setempat dengan bahan sampah.

5. Pengangkutan : merupakan hasil sampah yang telah terkumpulkan dan yang telah diseleksi kemudian diangkut oleh mitra kerja atau yang sudah terafiliasi untuk kemudian diuangkan kembali sesuai berat dan jenis sampah.

Pengelolaan sampah yang dilaksanakan oleh pemuda Katalog telah meliputi beberapa aspek seperti yang disebutkan sebelumnya, yaitu:

1. Bidang ekonomi

Di bidang ekonomi pemuda Karang Taruna Desa Klangonan (Katalog) merasakan dampaknya dari hasil program lingkungan (sampah) ini khususnya bagi organisasi pribadi. Chifdzul Maula yang akrab disapa Awik menjelaskan, bahwa posisinya yang memegang bidang kepemudaan dan kelompok usaha bersama awalnya mengajak diskusi dalam sebuah rapat tentang hasil tersebut. Dan kesepakatan yang didapat yaitu uang hasil program ini dibuat untuk menghidupi keuangan organisasi dalam melaksanakan kegiatan. Pemuda yang berumur 24 tahun ini mengaku bersyukur dengan adanya program ini, bisa membuka pola pikir pemuda desa dan juga lainnya bahwa uang bisa dihasilkan dari sesuatu yang dibuang oleh warga desa. ${ }^{23}$

Selanjutnya bapak Kamil juga mengungkapkan hal demikian dalam artian positif. Sebagai kepala desa Klangonan yang merasakan dampak dari adanya program sampah tersebut desa menjadi terbantu. Selain itu dalam hal financial setidaknya organisasi pemuda Karang Taruna Desa Klangonan (Katalog) mempunyai celengan mandiri sehingga tidak selalu tergantung pada

\footnotetext{
${ }^{23}$ Wawancara Muhammad Chifdzul Maula
} 
dana dari pemerintah desa. ${ }^{24}$ Artinya secara ekonomi kegiatan ini menghasilkan pendapatan asli daerah, atau pendapatan sendiri dengan memanfaatkan sumber daya yang ada.

Dalam buku "filsafat lingkungan hidup" karya A. Sonny Keraf mengungkapkan tentang bioregionalisme, sebuah istilah yang dikenalkan pertama kali oleh Allen Van Newkirk pada tahun 1970. Kemudian di lain sisi Berg dan Dasmann menjelaskan bahwa prinsip dasar bioregionalisme adalah hidup di tempat (living in place). Artinya masyarakat yang mempraktikkan "hidup di tempat" selalu akan menjaga keseimbangan daya dukung tempat melalui hubungan yang mendalam antara kehidupan dengan seluruh aktivitasnya. ${ }^{25}$ Ini seperti yang dilakukan oleh pemuda Karang Taruna Desa Klangonan (Katalog) dalam menerapkan living in place di mana perannya sebagai pemuda menjaga keseimbangan lingkungan desa. Selanjutnya juga dijelaskan bahwa keseimbangan yang dimaksud bertujuan untuk menciptakan masyarakat berkelanjutan, artinya kebiasaan hidup di mana ekonomi dan ekologi bersatu tanpa bisa dipisahkan. Jika biasanya konsep ini diterapkan seperti dalam kawasan desa wisata, maka pemuda pemuda Karang Taruna Desa Klangonan (Katalog) merespon dengan sudut pandang yang berbeda, yaitu dengan menghasilkan ekonomi dari kegiatan yang menciptakan keseimbangan lingkungan dalam kehidupan.

2. Bidang lingkungan

Di bidang lingkungan peran pemuda Karang Taruna Desa Klangonan (Katalog) terlihat lebih jelas dikarenakan isu yang dipermasalahkan dari awal adalah tentang lingkungan, khususnya sampah. Seperti yang diungkapkan oleh ketua Karang Taruna Desa Klangonan (Katalog), Zainul Chasin, bahwa dampaknya terhadap lingkungan termasuk signifikan. Karena dengan adanya program ini akhirnya beberapa hal yang seharusnya tidak dilakukan bisa berkurang seperti bau sampah atau asap hasil pembakaran sampah warga yang bisa berpotensi menimbulkan penyakit. ${ }^{26}$

\footnotetext{
${ }^{24}$ Wawancara Muhammad Kamiluddin

${ }^{25}$ A. Sonny Keraf, Filsafat Lingkungan Hidup, ..., h. 155.

${ }^{26}$ Wawancara ZC pada 15 Juli 2019.
} 
Kontribusi pemuda ini dalam teori peran mempunyai pengaruh pada tatanan perilaku masyarakat. Menurut Secord \& Backman (1964) berbagai istilah tentang perilaku dalam teori peran yaitu sebuah norma. Peran yang dilakukan oleh pemuda Karang Taruna Desa Klangonan (Katalog)terhadap lingkungan khususnya sampah secara tidak langsung menciptakan sebuah norma kembali bagi masyarakat, yaitu menyerahkan urusan sampah pada pemuda Karang Taruna Desa Klangonan (Katalog) dan tidak lagi membuang sembarangan atau membuang untuk kemudian dibakar.

Zainul musthafa, salah seorang warga desa Klangonan mengungkapkan bahwa dirinya menyikapi program tersebut dengan respon positif. Pasalnya rumahnya yang terdapat lahan kosong yang biasanya jadi tempat pembakaran sampah tetangga akhirnya berkurang secara volume, karena tetangganya mengikuti program sampah tersebut, walaupun tidak sepenuhnya bakar-bakar sampah itu hinlang setidaknya masih bisa berkurang. ${ }^{27}$

3. Bidang sosial

Dari segi sosial, program ini mempunyai nilai positif gotong royong dalam menjaga lingkungan desa atau rumah bagi warga. Karena pada mulanya sempat terjadi proses di mana setiap warga bertanggung jawab mandiri dalam bentuk membuang sendiri-sendiri sampahnya meskipun dari asal dan tujuan yang sama. Artinya pembuangan dilakukan dari desa Klangonan menuju Tempat Pemrosesan Sementara (TPS) di desa sekarkurung atau pasar tradisional Giri.

Bapak Muarif, ketua RW 2 mengungkapkan bahwa selain mengurangi tugas warga dalam menyikapi sampah, juga menciptakan hubungan yang harmonis antara pemuda dengan warga. Hal itu dikarenakan antara actor dan target merupakan sama-sama warga desa Klangonan yang mana secara tidak langsung mempunyai tanggung jawab bersama dalam menjaga lingkungan desa, dan itu terwujud dalam kerjasama program tersebut. ${ }^{28}$

Selain mempunyai dampak sosial dalam hal gotong royong, Ibrahim, selaku koordinator program mengungkapkan, dengan seringnya bertemu

\footnotetext{
${ }^{27}$ Wawancara ZM pada 11 Juli 2019

${ }^{28}$ Wawancara MR pada 11 Juli 2019
} 
dengan tetangga desa sendiri, tali silaturrahmi menjadi terus terjaga, dan ini tentu menjadi perisai atas terjadinya sikap asing terhadap tetangga sendiri. Secara sosial juga menciptakan adanya penyerapan tenaga kerja dan penguatan peran masyarakat.

\section{Analisis Aplikasi Pengelolaan Sampah Di Desa Klangonan}

Kegiatan yang dilaksanakan oleh pemuda Karang Taruna Desa Klangonan (Katalog) walaupun menurutnya hanya berorientasi pada membantu sesama warga untuk keluar dari masalah, secara etika lingkungan hidup perilaku pemuda menunjukkan seperti apa yang didefinisikan dalam teori ekosentrisme dan biosentrisme. Sikap pemuda dalam berhubungan dengan kehidupan di sekitarnya merepresentaskan sebuah keseimbangan hidup, di mana rasa tanggung jawab diri pada lingkungan adalah suatu hal yang perlu diterapkan di desa Klangonan.

Secara eksistensial manusia merupakan ciptaan (makhluk) layaknya ciptaanciptaan Allah SWT yang lainnya. Eksistensi manusia sebagai makhluk tidak pernah berubah hanya karena ia telah diangkat oleh Allah SWT sebagai khlaifah. Pada titik ini manusia dan alam adalah dua hal yang sama; makhluk ciptaan Allah yang samasama menjadi bukti eksistensi ketuhanan seperti yang termaktub dalam sura al Fushshilat ayat $53:^{29}$

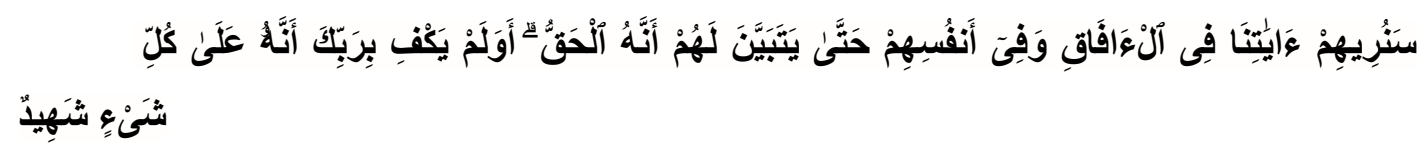

Kami akan memperlihatkan kepada mereka tanda-tanda (kekuasaan) Kami di segala wilayah bumi dan pada diri mereka sendiri, hingga jelas bagi mereka bahwa Alquran itu adalah benar. Tiadakah cukup bahwa sesungguhnya Tuhanmu menjadi saksi atas segala Sesuatu?. ${ }^{30}$

Berdasarkan dari pernyataan di atas program pengelolaan sampah yang dilaksanakan oleh pemuda Karang Taruna Desa Klangonan (Katalog) memberikan nilai positif dan nilai-nilai yang terkandung dalam prinsip-prinsip etika lingkungan hidup, yaitu:

1. Menumbuhkan jiwa peduli lingkungan

\footnotetext{
${ }^{29}$ Ahmad Khoirul Fata, Teologi Lingkungan Hidup Dalam Perspektif Islam, Jurnal Ulul Albab, Volume 15, No. 2, (2014).

${ }^{30}$ Alquran, 41:53.
} 
a. Sikap hormat terhadap alam (respect for nature)

Bersikap baik atau menghormati sesama makhluk adalah sebuah keharusan meskipun penciptaan manusia mempunyai nilai lebih dari makhluk lainnya. Hal ini dikarenakan manusia adalah bagian dari alam semesta, ibaratnya manusia adalah mikrokosmos dan alam adalah makrokosmos. Perilaku yang dilakukan oleh pemuda Karang Taruna Desa Klangonan (Katalog) dalam bentuk program sampah tersebut merupakan sebauh sikap dalam menghormati alam. Seperti yang disampaikan oleh Ibrahim dengan pendapatnya mengenai isu pencemaran atau kerusakan lingkungan, bahwa dengan menerapkan system jemput sampah pada warga, menjadikan warga tidak lagi membuang sampah sembarangan. Dan pencemaran atau kerusakan lingkungan itu terjadi karena kurang menjaganya manusia terhadap lingkungan sekitar. ${ }^{31}$

Hal tersebut mengandung sebuah hukum kausalitas bagi warga dan alam sebagai wadah manusia tempat tinggal. Seperti yang dijelaskan oleh Paul Taylor dalam paham biosentrismenya, bahwa ada perbedaan antara manusia dengan alam, di mana ada pelaku moral (moral agents) dan selain manusia yang bisa diperlakukan secara baik dan buruk atau disebut dengan subyek moral (moral subject). Paul mengatakan bahwa meskipun batu, air, udara dan lainnya yang tak bernyawa bukan merupakan pada subyek moral pada dirinya sendiri, namun benda abiotik ini tetap harus diperlakukan secara baik karena benda tersebut juga menentukan kehidupan subyek moral. Seperti halnya ketika warga dengan sengaja membiarkan sampah menumpuk dan membusuk di lingkungannya, maka akan berpengaruh pada kesehatan manusia karena di situ berpotensi menimbulkan bau yang tidak sehat dan juga beberapa binatang jahat serta kuman di dalamnya.

Sikap hormat terhadap alam juga diajarkan dalam Islam sebagai agama rahmatan lil 'alamin. Islam mengajarkan bahwa manusia dan alam adalah makhluk Allah yang sama-sama ciptaan-Nya, dan manusia sebagai

${ }^{31}$ Wawancara MIS pada 13 Juni 2019. 
makhluk berakal mempunyai tugas untuk menjaganya dengan menghormatinya, seperti dalam surat al-Anbiya'ayat 107:

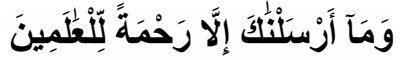

Dan tiadalah Kami mengutus kamu, melainkan untuk (menjadi) rahmat bagi semesta alam. ${ }^{32}$

b. Prinsip tanggung jawab (moral responsibility for nature)

Tanggung jawab ini bukan hanya bersifat individual melainkan kolektif. Artinya tanggung jawab bukan atas kepentingan pribadi melainkan tugas manusia sebagai satu kesatuan dalam komunitas ekologis. Prinsip ini sangat perlu digarisbawahi, melihat teori terdahulunya yaitu antroposentrisme yang mengatakan bahwa yang perlu menerima perlakuan moral hanyalah manusia, sedangkan lainnya tidak. Ini menjadi sangat merugikan lingkungan sebagai makhluk yang bukan manusia, sedangkan manusia mempunyai kekuasaan lebih dengan akalnya dalam memanfaatkan lingkungan di sekitarnya.

Perilaku pemuda Karang Taruna Desa Klangonan (Katalog) dalam hal menertibkan sampah sebagai bentuk kepedulian lingkungan merupakan respon tanggung jawabnya sebagai manusia di lingkungan desanya. Dalam teori ekosentrisme di manaArne Naess mengungkapkan bahwa dalam istilah ecosophy yang dipopulerkan olehnya adalah sikap peduli pada lingkungan yang bukan hanya bersifat teoritis, melainkan lebih kepada praktis sehingga tercipta juga gerakan-gerakan peduli lingkungan sebagai manusia penghuni bumi. Pemuda Karang Taruna Desa Klangonan (Katalog) melakukan sebuah tanggung jawab sebagai manusia yang hubungannya dengan benda abiotis. Dalam paham ekosentrisme, pemuda Karang Taruna Desa Klangonan (Katalog) mencerminkan bagian dari teori tersebut dengan menaruh sikap pada benda abiotis yang mana manusia dan lainnya merupakan sebuah komunitas ekologis.

Islam mengajarkan tentang tanggung jawab baik pada diri sendiri maupun terhadap lainnya, termasuk dengan alam seperti hakikat manusia

\footnotetext{
${ }^{32}$ Alquran, 21:107.
} 
yang diciptakan sebagai khalifah di bumi, hal ini termaktub dalam surat alBaqarah ayat 30:

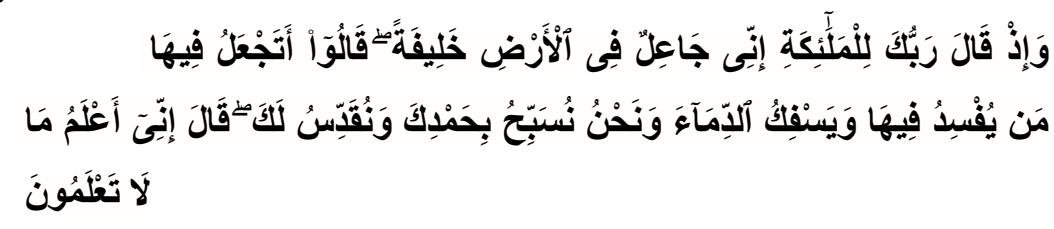

Ingatlah ketika Tuhanmu berfirman kepada para Malaikat:"sesungguhnya Aku hendak menjadikan seorang khalifah di muka bumi". Mereka berkata:"Mereka engkau hendak jadikan (khalifah) di bumi itu orang yang akan membuat kerusakan padanya dan menumpahkan darah, padahal kami senantiasa bertasbih dengan memuji Engkau dan mensucikan Engkau?" Tuhan berfirman:"Sesungguhnya Aku mengetahui apa yang tidak kamu ketahui". 33

c. Prinsip kasih sayang dan kepedulian terhadap alam (caring for nature)

Prinsip ini dipahami sebagai prinsip satu arah. Artinya kasih sayang dan kepedulian yang diberikan kepada alam adalah satu arah tanpa mengharapkan balasan apalagi hanya dilakukan ketika mempunyai nilai keuntungan bagi manusia. Dalam perspektif Deep Ecology justru ketika manusia mencintai alam, manusia menjadi semakin kaya dan semakinmerealisasikan dirinya sebagai pribadi ekologis. Manusia semakin tumbuh bersama alam, dengan segala watak dan kepribadian yang tenang, damai, dan penuh kasih sayang.

Dalam praktiknya, pemuda Karang Taruna Desa Klangonan (Katalog) menjadi actor dalam menumbuhkan sikap kasih sayang dan peduli terhadap lingkungan. Hal itu terjadi karena mereka adalah pelaku peduli lingkungan yang bukan hanya sekadar teritis melainkan dalam bentuk gerakan. Sikap kasih sayang adalah sikap baik dan diajarkan oleh semua agama, tak terkecuali Islam yang menjadi simbol agama ramah bukan marah. Meskipun tanpa melupakan kehidupan dunianya, Alquran juga mengingatkan saling berbuat baik untuk bekal akhirat kelak seperti yang termaktub dalam surat al-Qashash ayat 77:

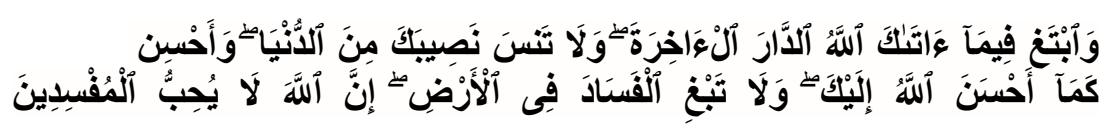

${ }^{33}$ Alquran: 2:30. 
Dan carilah pada apa yang telah dianugerahkan Allah kepadamu (kebahagiaan) negeri akhirat, dan janganlah kamu melupakan bahagiamu dari (kenikmatan) duniawi dan berbuat baiklah (kepada orang lain) sebagaimana Allah telah berbuat baik kepadamu, dan janganlah kamu berbuat kerusakan di (muka) bumi. Sesungguhnya Allah tidak menyukai orang-orang yang berbuat kerusakan. ${ }^{34}$

2. Membangkitkan cara pandang pembangunan berwawasan lingkungan

a. Prinsip keadilan

Prinsip keadilan berbicara tentang bagaimana manusia harus berperilaku satu terhadap yang lain dalam kaitan dengan alam semesta dan bagaimana system sosial harus diatur agar berdampak positif pada kelestarian hidup. Dalam hal ini, prinsip keadilan berbicara tentang akses yang sama bagi semua kelompok dan anggota masyarakat dalam ikut menentukan kebijakan pengelolaan sumber daya alam dan pelestarian alam, dan dalam ikut menikmati pemanfaatan sumber daya alamnya. ${ }^{35}$

Dengan pemuda Karang Taruna Desa Klangonan (Katalog) yang terlibat langsung dalam pergulatan lingkungan, pemuda lebih mempunyai rasa peduli tinggi terhadap lingkungan desanya. Maksudnya adalah sebagai organisasi yang berada di bawah naungan pemerintah desa, Karang Taruna Desa Klangonan (Katalog) mempunyai kesempatan untuk menyampaikan pandangannya dalam hal pembangunan desa yang berwawasan lingkungan. Itu sangat mungkin dilakukan karena dalam setipa perencanaan pembangunan yang melibatkan banyak unsur salah satunya adalah unsure pemuda.

Secara garis besar permasalahan lingkungan hingga sisi kecilnya, pemuda Karang Taruna Desa Klangonan (Katalog) mempunyai potensi lebih dalam menyampaikan aspirasinya sehingga peranan pemuda semakin terlihat di tengah pembangunan desa, dan tentunya pembangunan yang mempunyai nuansa lingkungan. Bagaimanapun selama tidak ada yang mengusulkan hal tersebut, cara pandang pembangunan akan tetap sama.

\footnotetext{
${ }^{34}$ Alquran, 28:77.

${ }^{35}$ A. Sonny Keraf, Etika Lngkungan Hidup, ..., h. 177.
} 
Dalam agama Islam juga menekankan bahwa manusia dalam perubahannya adalah usaha yang tanpa menemui berhenti, selalu berjuang agar memperoleh kehidupan yang lebih baik dengan bermula pada dirinya sendiri. Hal ini sesuai dengan surat al-Ra'd ayat 11:

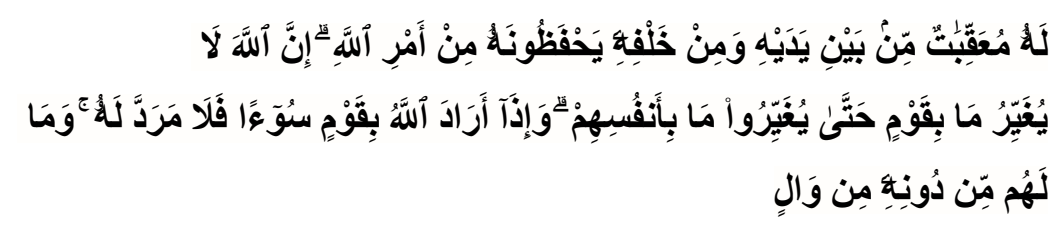

Bagi manusia ada malaikat-malaikat yang selalu mengikutinya bergiliran, di muka dan di belakangnya, mereka menjaganya atas perintah Allah. Sesungguhnya Allah tidak merubah keadaan suatu kaum sehingga mereka merubah keadaan yang ada pada diri mereka sendiri. Dan apabila Allah menghendaki keburukan terhadap sesuatu kaum, maka tak ada yang dapat menolaknya; dan sekali-kali tak ada pelindung bagi mereka selain dia. ${ }^{36}$

b. Prinsip integritas moral

Prinsip integritas moral merupakan sebuah prinsip yang lahir dari sebuah teori etika lingkungan hidup yang tidak mengedepankan kepentingan manusia sebagai kepentingan pribadi atau kepentingan satusatunya. Prinsip ini diperuntukkan bagi pemegang otoritas kebijakan dalam menciptakan keputusan terhadap lingkungan. Belakangan dampak dari kemajuan teknologi memnjadikan gradasi moral turun terutama bagi remaja dan pemuda dalam berhubungan. Ini perlu ditekankan dalam menjalankan amanah dengan integritas moral.

Kaitannya dengan pemuda Karang Taruna Desa Klangonan (Katalog) yaitu sebagai pelaku dalam program yang berbasis peduli lingkungan, pemuda Karang Taruna Desa Klangonan (Katalog) diciptakan untuk menjadi pribadi yang berintegritas moral dalam hal menyikapi lingkungan. Hal ini merupakan sebuah pandangan masa depan di mana pemuda yang terlibat di dalam pengembangan dan pembangunan desa nantinya bisa mempunyai arah yang lebih jelas dalam hal menentukan kebijakan yang berhubungan dengan lingkungan.

\footnotetext{
${ }^{36}$ Alquran, 13:11.
} 
Ketika integritas moral ini terkikis dan tidak ada yang peduli, maka pembangunan desa yang berkelanjutan dan berwawasan lingkungan akan sulit diimplementasikan atua mungkin hanya masuk dalam draft perencanaan saja tanpa terus dilaksanakan. Sebagai pemuda yang nantinya akan menjadi penerus tongkat kepemimpinan, pemuda Karang Taruna Desa Klangonan (Katalog) mempunyai potensi dalam hal tersebut. Prinsip ini adalah prinsip yang mempunyai kandungan ekosentris dan sekaligus antroposentris dalam hal wewenang kebijakan namun dalam pandangan Islam, artinya kemampuan manusia sebagai makhluk yang mendapat mandat memelihara lingkungannya dengan menghindari kerusakankerusakan akibat lalainya manusia dalam beretika. Sudah cukup banyak terlihat kerusakan-kerusakan di negara Indonesia pada umumnya dengan skala besar, ini menjadi gambaran bagi pemuda Karang Taruna Desa Klangonan (Katalog) agar supaya bisa menjaga linkgungan desa Klangonan yang mana kondisi lingkungannya tergolong minim dari industry-industri besar. Dalam agama Islam sudah diberikan peringatan melalui Alquran dalam surat al-Rum ayat 41:

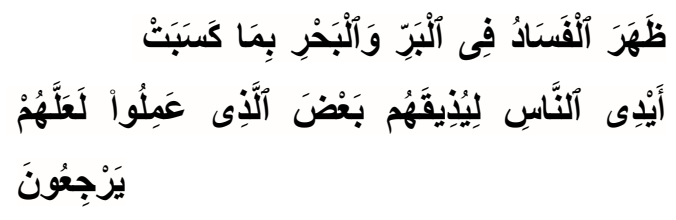

Telah nampak kerusakan di darat dan di laut disebabkan karena perbuatan tangan manusia, supaya Allah merasakan kepada mereka sebahagian dari (akibat) perbuatan mereka, agar mereka kembali (ke jalan yang benar). ${ }^{37}$

\section{Kesimpulan}

Peran pemuda desa Klangonan terhadap lingkungan terangkum dalam program kegiatan Karang Taruna Desa Klangonan atau disingkat Katalog dalam hal pengelolaan sampah. Peran yang dilaksanakan sejak tahun 2016 hingga sekarang. Meskipun secara legalitas kepengurusan Karang Taruna Desa Klangonan

\footnotetext{
${ }^{37}$ Alquran, 30:41.
} 
turun pada tahun 2017, namun ide untuk berkontribusi pada pembangunan desa khususnya lingkungan tetap dijalankan.

Strategi yang digunakan pemuda dalam menyikapi lingkungan desa adalah dengan membuat sebuah program yang berawal dari keresahan masyarakat, kemudian dituangkan dalam sebuah pergerakan. Ada beberapa tahapan yang dilewati yaitu dari sosialisasi kepada warga dan dengan dukungan pemerintah desa. Dalam pelaksanaannya pemuda Karang Taruna Desa Klangonan menerapkan sistem terjadwal dengan lokasi dan waktu yang berbeda, di mana di desa Klangonan dibagi menjadi 2 bagian antara Rt 1 sampai dengan 6, kemudian di hari selanjutnya Rt 7 sampai 13. Sistem jasa ini juga memberi pemasukan bagi Karang Taruna Desa Klangonan karena dalam setiap pengambilan, masyarakat bisa memberikan kontribusi berupa uang.

Dalam upaya pelaksanaannya, program pengelolaan sampah yang dilaksanakan oleh pemuda Karang Taruna Desa Klangonan mendapat sambutan positif dari masyarakat, juga dari pemerintah desa. Dalam pengaplikasiannya program sampah tersebut, menciptakan sebuah dampak positif dengan menurunnya orang buang sampah sembarangan atau buang sampah langsung dibakar.

\section{Daftar Pustaka}

A. Sonny Keraf, 2010, Etika Lingkungan Hidup, Jakarta: PT. Kompas Media Nusantara. A. Sonny Keraf, 2104, Filsafat Lingkungan Hidup, Yogyakarta: PT. Kanisius.

Ahmad Khoirul Fata, 2014, Teologi Lingkungan Hidup Dalam Perspektif Islam, Jurnal Ulul Albab, Volume 15, No. 2.

Alquran dan terjemahan

Amurwaraharja, I.P, Analisis Teknologi Pengolahan Sampah Dengan Proses Hirarki Analitik dan Metoda Valuasi Kontingensi (Studi Kasus di Jakarta Timur), (Institut Pertanian Bogor, Tesis, 2003).

G. Theisen Tchobanoglous, dan S. A. Vigil, 1993, Integrated Solid Waste Management Engineering Principles and Management Issues. Singapore, Mc. Grw Hill. 
Gresiknews.co, Kesadaran Mengelola Sampah di Gresik Masib Minim, 23 Oktober 2019..

Mahyudin, R.P, Strategi Pengelolaan Sampah Berkelanjutan, EnviroScientae, 10: 33-40.

Rizqi Puteri Mahyudin, 2014, Strategi Pengelolaan Sampah Berkelanjutan, Jurnal Enviro Scientiae, 10.

Sarlito Wirawan Sarwono, 2017, Teori-teori Psikologi social, Jakarta: PT. RajaGrafindo Persada.

Takdir Rahmadi, 2014, Hukum Lingkungan di Indonesia, Jakarta: Rajawaloi Press.

Undang-Undang Nomor 23 Tahun 1997 tentang Pengelolaan Lingkungan Hidup 